\title{
精神的健康・幸福度をめぐる新たな二者関係理論と その実証方法
}

\section{浅野 良輔 ${ }^{1}$ 浜松医科大学 五十嵐 祐 名古屋大学}

\author{
"Individual-dyad dynamics": A new perspective and empirical methods for understanding \\ mental health and well-being
}

\begin{abstract}
Ryosuke Asano (Hamamatsu University School of Medicine) and Tasuku Igarashi (Nagoya University)
\end{abstract}
\begin{abstract}
Dyadic relationships play a pivotal role in mental health and well-being. Although individual-level factors such as self-esteem and attachment style have been widely studied, the psychological constructs shared and emerging in dyadic relationships have not been explored adequately. This article introduces a novel approach called "individual-dyad dynamics" for understanding mental health and well-being, and provides an overview of dyadic data analysis methods. The approach examines processes involved in dyadic relationships at both the individual and dyad level. Utilizing the tenets of social cognitive theory and social capital theory, we propose that shared relational efficacy, which refers to two individuals having common efficacy expectations and subjectively experiencing commonality in expectations, is distinguishable from perceived relational efficacy. The article discusses the nature of shared relational efficacy from both theoretical (i.e., self-efficacy and shared reality) and analytical (i.e., multilevel structural equation modeling) perspectives. We summarize past empirical research providing preliminary support for this approach and outline implications and future directions regarding dyadic relationship studies.
\end{abstract}

Key words: mental health, well-being, dyadic relationships, individual-dyad dynamics, shared relational efficacy.

The Japanese Journal of Psychology

2015, Vol. 86, No. 5, pp. 481-497

J-STAGE Advanced published date: September 15, 2015, doi.org/10.4992/jjpsy.86.14401

社会科学の分野では，個人の心理的適応がどのよう にして達成されるのかについて, 精神的健康, 快楽主 義 (hedonism: Kahneman, Diener, \& Schwarz, 1999), 幸 福主義 (eudaimonism: Ryan \& Deci, 2001) の観点から, さまざまな検討がなされている。快楽主義は，人生満 足度やポジティブ感情の高さ，ネガティブ感情の低さ を重視する立場であり，幸福主義は，人格的成長，人 生の意味，自律性などの“よい人生”を重視する立場

Correspondence concerning this article should be sent to: Ryosuke Asano, Research Center for Child Mental Development, Hamamatsu University School of Medicine, Handayama, Higashi-ku, Hamamatsu 431-3192, Japan（e-mail: asano.r1984@gmail.com)

本論文の執筆に際して, 金政 祐司先生 (追手門学院大学), 相馬 敏彦先生 (広島大学), 清水 裕士先生 (関西学院大学) より, 社会心理学的な観点から建設的なご意見を頂戴し, 荘島 宏二郎 先生（大学入試センター）より，統計分析に関する貴重なご助 言を賜りました。厚く御礼申し上げます。
である。本論文では，こうした精神的健康や幸福度の 規定因として，社会的ネットワーク，とくに二者関係 (ダイアド)を取り上げる。

社会的ネットワークは, 個人の精神的健康や幸福度 の源泉として, その重要性が繰り返し指摘されてきた。 ソーシャル・サポートが精神的健康を維持・増進する 一方で (Cohen \& Wills, 1985; House, Landis, \& Umberson, 1988; 浦, 1992), 社会的排斥や対人ストレスは精神的 健康を阻害する（Eisenberger \& Cole, 2012; 橋本, 2005; 浦, 2009)。また, 年齢, 性別, 学歴, 職業, 所得など よりも, 社会的ネットワークは幸福度に対して強い影 響を与えることが一貫して示されている (Kahneman \& Krueger, 2006; 大石, 2009; Ryan \& Deci, 2001)。

それでは, 個人の精神的健康や幸福度を規定すると される社会的ネットワーク，とくに二者関係について は，これまでどのような検討がなされてきたのだろう か。従来の研究では, 個人一人ひとりの“こころ”ゃ 
“あたま”のなかに二者関係の本質が還元され，そう した個人レベルの影響プロセスが精神的健康や幸福度 を予測するとの立場がとられてきた。たとえば，ある 特性をもつ個人は, その特性をもたない個人よりも, 良好な二者関係を築くことで精神的健康や幸福度が高 くなる（あるいは低くなる）という説明は，個人一人 ひとりの“こころ”や“あたま”に依拠した説明の典 型といえる。しかし，二者関係を源泉とした精神的健 康や幸福度は，個人レベルの影響プロセスだけで説明 できるわけではない。むしろ，どちらの個人にもみら れない二者関係そのものの性質もまた，個人の精神的 健康や幸福度に影響していると考えるほうが妥当だろ う。

本論文の目的は, (a) 個人の精神的健康や幸福度の 基盤としての二者関係のメカニズムをより精緻にとら えるために, “個人-関係のダイナミックス” (Figure 1) の視座を新たに導入すること, さらに，(b)このアプ ローチを実証研究の组上に載せるため, ダイアドデー 夕の分析方法について議論することである。“個人-関 係のダイナミックス”の視座では, 従来の心理学で検 討されてきた個人レベルの影響プロセスに加えて，二 者関係における相互依存性によって創発された，ダイ アドレベルの影響プロセスにも焦点を当てる。これら 二つの影響プロセスは, 個人ではなく, ダイアドを分 析単位とすることで検討が可能になる。

本論文ではまず，二者関係が個人の精神的健康や幸 福度に与える影響にまつわる先行研究を概観し, 個人 レベルの説明変数のみに注目することの問題点を明ら かにする。つぎに, 集団や近隣地域に関する研究動向 を踏まえ，個人の精神的健康や幸福度を “個人一関係 のダイナミックス”の視座から説明するアプローチの 一つとして，二者間で共有されたダイアドレベルの効 力期待を取り上げる。さらに，二者間で共有された効

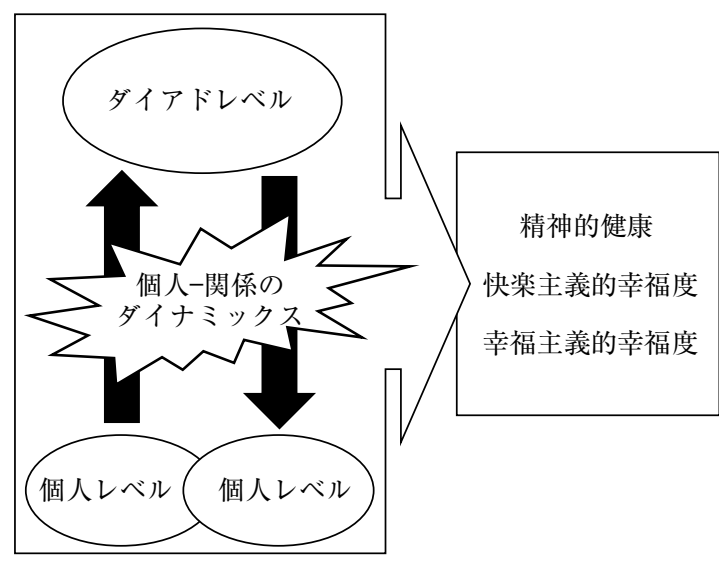

Figure 1. 個人の精神的健康や幸福度を “個人-関係の夕゙ イナミックス”によって説明する視座
力期待を検証するため, ダイアドデータの分析方法に ついて議論する。最後に, 本論文のアプローチと関わ りの深い実証研究を概観するとともに, 将来の研究の 方向性を展望する。

\section{二者関係と精神的健康 - 幸福度}

この節では，二者関係が個人の精神的健康や幸福度 に与える影響を説明する代表的な理論として, ソシオ メーター理論 (sociometer theory) と成人の愛着理論 (adult attachment theory) を取り上げる。ソシオメー ター理論があらゆる社会集団を射程としているのに対 して, 成人の愛着理論は特定の他者との親密な関係に 焦点を当てている。こうした相違はあるものの, 二つ の理論は, 所属欲求 (need to belong) や愛着といった 進化心理学的な背景から個人の精神的健康や幸福度を 説明し, 現在の社会・パーソナリティ心理学の領域に おいて多くの知見を積み重ねている。なお本節では, 個人レベルの説明変数としての特性自尊心（trait selfesteem) や愛着スタイル (attachment style) が, 二者関 係の質, さらには精神的健康や幸福度を規定するとい う個人レベルの影響プロセスに限定してレビューを行 う。

\section{ソシオメーター理論}

ソシオメーター理論 (Leary, 2005; Leary \& Baumeister, 2000）によると，低い特性自尊心をもつ個人は，社会 集団において所属欲求を満たすことができずに, 精神 的健康や幸福度を低下させやすい。特性自尊心は，他 者からの受容-排斥のライフヒストリーによって形成 され, 時間や状況を通じて安定した自己肯定の感覚で ある (Leary \& Baumeister, 2000)。これは, 状況ごとに 刻々と変動する感情体験としての状態自尊心 (state self-esteem）とは区別される。特性自尊心の低さは, 自 分が他者から受容されることはこれからもないだろ う，という自己へのネガティブな期待を意味する (Leary, Tambor, Terdal, \& Downs, 1995)。特性自尊心の 低い個人は，(a) 自分がいつか他者から排斥されるに ちがいないと恐れるがゆえに，(b) 自己や他者の欠点 にばかり注目し, (c) 不安, 敵意, 䃚妬といったネガティ ブ感情を喚起させるため, (d) 実際に他者との関係を 悪化させやすい (Leary, 2005; Leary \& Baumeister, 2000)。したがって, 特性自尊心の低さは, 他者から の排斥という最も避けるべき事態を導くことで (Murray, Rose, Holmes, Derrick, Podchaski, Bellavia, \& Griffin, 2005), 個人の精神的健康や幸福度を低下させ てしまう。

\section{成人の愛着理論}

成人の愛着理論 (Bowlby, 1988; Feeney, 2004; Feeney \& Collins, 2015）によれば, 不安定な愛着スタイルを 
もつ個人は，親密な関係において安全な避難所（safe haven）と安全基地（secure base）を確保しにくいため, 精神的健康や幸福度が低い傾向にある。とくに，“自 分には他者から受容される価值がない”といった自己 へのネガティブな期待である関係不安 (attachmentanxiety）は, “他者は自分の要求に応えてくれない” といった他者へのネガティブな期待である親密性回避 (attachment-avoidance) よりも，精神的健康や幸福度に 深刻な影響を与えるだろう（Bartholomew \& Horowitz， 1991; Simpson \& Rholes, 2004 金政訳 2008)。関係不安 の高い人々は, (a) 自分が相手から拒絶されるかもし れないという懸念や恐れから，(b) 相手に対して過剩 な要求をしたり，自分を受容しているかどうかを執拗 に確認したりして，（c）怒り，姤妬，焦りといったネ ガティブ感情を喚起させるため, (d) 実際に他者との 関係を悪化させやすい（Mikulincer \& Shaver, 2003）。 そのため, 関係不安の高さは, 親密な他者からの望ま ない拒絶を招き（金政, 2009, 2010)，個人の精神的健 康や幸福度を低下させてしまう。

\section{個人レベルのアプローチの成果と限界}

このように，ソシオメーター理論および成人の愛着 理論において, 良好な二者関係は, 所属欲求の充足と, 安全な避難所や安全基地の確保につながり, 個人の精 神的健康や幸福度の源泉になると仮定されている。こ の点については, 社会・パーソナリティ心理学の分野 で多くの知見が積み重ねられており（Feeney \& Collins, 2015; Leary, 2005)，これ以降，本論文では議論の対象 としない。

本論文がこれまでの研究を批判的に吟味しようとし ているのは, 個人の精神的健康や幸福度の源泉となる 二者関係の性質が，特性自尊心や愛着スタイルといっ た個人レベルの説明変数のみに還元されてきた点であ る。ただし，本論文は，個人レベルのアプローチを採 用した先行研究のすべてを批判するものではない。本 節で概観した通り，低い特性自尊心や不安定な愛着ス タイルをもつ個人は, 相手に対する認知や行動を過剩 にネガティブな方向にゆがめ，二者関係を悪化させや すい（金政, 2009, 2010; Murray et al., 2005)。こうした 個人が, 所属欲求の未充足や, 安全な避難所と安全基 地の不在によって, 精神的健康や幸福度を低める可能 性は十分に考えられる。

その一方で, これまでの研究は, 特性自尊心や愛着 スタイルといった個人レベルの説明変数が, 個人の精 神的健康や幸福度に対して一定の予測力をもつと同時 に，その効果はあくまでも限定的であることを示して いる。特性自尊心に関するレビュー論文では, 個人の 精神的健康や幸福度との関連は膨大に報告されている が, 変数間の因果関係についてはいまだ検討の余地が あるとされている (Baumeister, Campbell, Krueger, \&
Vohs, 2003)。また，特性自尊心と抑うつとの関連を検 討した 77 編の縦断研究に対するメ夕分析の結果 (Sowislo \& Orth, 2013) は，抑うつの高さが特性自尊 心を低くするというよりも，特性自尊心の低さが抑う つを高めるという因果関係の妥当性を示唆している が，その効果量 $(\beta=.16)$ は必ずしも大きいとはいえ ない。さらに, 愛着スタイルの関係不安, ならびに親 密性回避と抑うつとの関連を検討した場合も，弱い相 関から中程度の相関にとどまることが多い（Rholes， Simpson, Kohn, Wilson, Martin, Tran, \& Kashy, 2011; Simpson, Rholes, Campbell, Tran, \& Wilson, 2003)。以上 のことから, 二者関係が個人の精神的健康や幸福度に 影響するメカニズムを理解するためには, 特性自尊心 や愛着スタイルだけでなく，その他の説明変数にも注 目する必要があるといえよう。

そこで本論文では，二者関係がどのようにして個人 の精神的健康や幸福度の源泉となるのかを明らかにす るため, ダイアドレベルの説明変数に焦点を当てる。 Lewin（1947）は，夫婦関係を例に，個人間の相互依 存性が一人ひとりには還元できない二者関係に特有の 性質を創発させるとともに，このような創発された性 質が個人の行動傾向や心理プロセスに影響するとい う，個人レベルとダイアドレベルのダイナミックスに ついて議論している。Lewin（1947）の主張は, 相互 依存性理論 (interdependence theory: Kelley \& Thibaut, 1978 黒川監訳 1978）としてその後さらに洗練されて いったものの，二者関係にまつわる理論や分析の視点 は, 依然として個人レベルにとどまったままであった。 また, Berscheid (1999) は, 二者関係の本質を, 態度 やパーソナリティ特性といった個人の“こころ”，な いしは“あたま”のなかだけに還元することはできな いと指摘した。この指摘以降, 二者関係研究 (Acitelli, Duck, \& West, 2000; Campbell \& Rubin, 2012) や対人コ ミュニケーション研究 (Ickes, Hutchison, \& Mashek, 2004）において，ダイアドレベルの影響プロセスに着 目した論考が再び盛んになりつつある。しかし, ダイ アドレベルの説明変数が個人の精神的健康や幸福度に 与える影響に関する実証研究は，いまだほとんどなさ れていないのが現状である。

ダイアドレベルの説明変数について検討すること は，二者関係の特徴や性質を明らかにしようとする研 究のみならず, それらが個人の精神的健康や幸福度に 与える影響を理解しようとする研究にとっても重要な 意味をもつ。Oishi, Kesebir, \& Snyder (2009) は, それ までの幸福度に関する心理学的研究が, パーソナリ ティ特性, 社会経済的地位, 社会関係の質に対する主 観的評価といった個人レベルの現象にばかり焦点を当 て，ダイアドレベルの現象には目を向けてこなかった と批判している。上述のように, 二者関係は, 個人レ ベルの影響プロセスとダイアドレベルの影響プロセス 
から成り立っている (Berscheid, 1999; Lewin, 1947)。 そのため, 個人レベルの構成概念として位置づけられ る精神的健康や幸福度に対して，二者関係が与える影 響をより深く理解するためには, 個人レベルの影響プ ロセスだけでなく，ダイアドレベルの影響プロセスに も注目する必要があるだろう。

ただし，これまでの心理学において，ダイアドレべ ルの影響プロセスがまったく注目されてこなかったわ けではない。たとえば, 対人魅力研究における類似性 一魅力仮説は，二者のどちらか一方だけには還元でき ない, 自己と他者の類似性が，相手に対する自己の好 意度を高めることを示している (Byrne \& Nelson, 1965)。また，夫婦間での愛着スタイルや神経症傾向 の高低の組み合わせが, 夫婦関係の質を規定すること (Ben-Ari \& Lavee, 2005)，あるいは二者間のパーソナ リティ特性の類似性が, 恋人や配偶者との感情体験の 類似性や関係満足度を高めること (Gonzaga, Campos, \& Bradbury, 2007) が明らかとなっている。

さらに, 二者関係の文脈でとくに研究が進められて いる現象として, 情動伝染 (emotional contagion) があ る。情動伝染とは, 発話, 表情, 姿勢などの模倣や同 期が自動的に生じることで，人々が類似した感情状態 を経験することを指し, (a) 模倣, (b) フィードバック, (c) 伝染の三つのメカニズムを通じて生起する (Hatfield, Cacioppo, \& Rapson, 1993)。発話, 表情, 姿 勢などの模倣は自動的かつ継続的に生じており，そう した模倣からのフィードバックが，個人の感情状態に 対して常に影響する。その結果, 他者の感情状態は, そのときどきで個人の感情状態に伝染するのである。 また，情動伝染は，言語行動よりも非言語行動に基づ いており，自動的で非意識的に生じると仮定されてい る(Barsade, 2002)。二者関係に扔ける情動伝染の具体 例としては，恋愛カップルや同性のルームメイト・ペ アを対象とした 6 カ月から 9 力月にわたる縦断研究に おいて, 参加者の感情体験が次第に類似していくこと が報告されている(Anderson, Keltner, \& John, 2003)。 しかし, これらの研究は, 個人レベルの影響プロセス とダイアドレベルの影響プロセスの区別を目的として おらず，個人の精神的健康や幸福度を規定する二者関 係の性質を明らかにするためには，より詳細な議論が 必要と考えられる。

以上のように, 二者関係が個人の精神的健康や幸福 度に影響を与えるメカニズムを明らかにする際に, 個 人レベルの影響プロセスに加えて, ダイアドレベルの 影響プロセスに焦点を当てることは重要な意味をも つ。しかし, 実証研究では依然として, ダイアドレベ ルの説明変数は十分に検討されていない。そこで本論 文では, “個人-関係のダイナミックス”の視座を採用 し, 二者間の相互依存性に基づいた新たな構成概念を 提案する。

\section{“個人-関係のダイナミックス”の視座に向けて}

個人の精神的健康や幸福度を“個人一関係のダイナ ミックス”の視座から説明する本論文のアプローチは, 集団レベルの影響プロセスを扱う社会認知理論 (social cognitive theory) や社会関係資本論 (social capital theory）との親和性が高い。本節では, これら の理論を概観した後, ダイアドレベルの説明変数とし て, 共有された関係効力性 (shared relational efficacy) に注目し，その特徴や他の概念との違いについて議論 する。

\section{社会認知理論}

Bandura（1997）の社会認知理論は, 効力期待 (efficacy expectations) の観点から, 人々が目標を達成 したり，高い成果を得たりするプロセスを説明してい る。効力期待とは, 目標達成のために必要な行動を計 画・遂行できるという予期を指し, ある行動が目標達 成につながるという予期である結果期待 (outcome expectations）とは区別される。とくに, “わたしは目 標を実現するために必要な行動をとることができる” といった自己効力感 (self-efficacy) の概念は, 心理学 以外の領域においても広く関心を集めている (Bandura, 1997, 2001)。

社会認知理論の注目すべき点は, 個人レベルの効力 期待だけでなく, 集団レベルの効力期待, すなわち集 合効力性 (collective efficacy) を仮定していることにあ る。集合効力性とは, “われわれの集団は目標を実現 するために協力し合うことができる”といった, 集団 全体としての行動を協力して計画・遂行できるかどう かに関するメンバー間で共有された効力期待と定義さ れる (Bandura, 1997, 2001)。集合効力性の高さは, 個 人一人ひとりの自己効力感の総和ではとらえることの できない, メンバー間の相互調整 (coordination) や相 互協調（cooperation）をうながす (Zaccaro, Blair, Peterson, \& Zananis, 1995)。集合効力性は, スポーツ, 学校, 組織, 軍隊, 政治, 地域社会などさまざまな分 野で効果を発揮し, メ夕分析においても, 集団パフォー マンスとの中程度の関連が確認されている (Gully, Incalcaterra, Joshi, \& Beaubien, 2002; Stajkovic, Lee, \& Nyberg, 2009)。これらの知見から, 集団レベルの説明 変数である集合効力性の高さは, 個人の精神的健康や 幸福度に対してポジティブな効果をもつことが考えら れる。

なお, 集合効力性は, 集合心や集団心といった集団 錯誤 (group fallacy) を引き起こす概念ではない。社会 心理学では, 集団全体に“こころ”を仮定した社会現 象の説明は論理的矛盾に陥る, との批判が繰り返しな されている (Allport, 1924; 亀田・村田, 2010)。しかし, 集合効力性は, あくまでも個人一人ひとりの行動を基 
盤とした相互依存性によって創発された概念であり， 集団錯䛊にはあたらない (Bandura, 1997, 2001)ㄹㅇ本論 文でも，こうした方法論的個人主義の立場から以降の 論を進める。

\section{社会関係資本論}

社会関倸資本は，協調関係に基づく社会的ネット ワークと, そこから生み出される互恵性規範や信頼を 包含した複合的な概念であり，個人の精神的・身体的 健康や幸福度の増進をうながすとされている (Putnam, 2000 柴内訳 2006)。社会関係資本論では, 個 人がもつネットワークや信頼といった個人レベルの社 会関係資本と，集団内のネットワーク構造や共有され た互恵性規範といった集団レベルの社会関係資本をそ れぞれ区別して扱う。これによって，“社会関係資本 にそしい個人であっても，社会関係資本の豊かな地域 社会に住むことで，安心して暮らすことができる” (Putnam, 2000 柴内訳 2006 p. 16)，といった異なるレ ベルでの交互作用効果を仮定できる。

集団レベルの社会関係資本の一つとして, 近隣地域 の集合効力性 (neighborhood collective efficacy) が注目 されている。近隣地域の集合効力性は, 地域住民にお ける相互信頼と，公共財の保持に積極的に関わること ができるといった信念を含む住民間で共有された効力 期待と定義され，子どもの非行，住民の犯罪行為や抑 うつ症状といったさまざまな問題行動を予測する (Sampson, Morenoff, \& Gannon-Rowley, 2002; Sampson, Raudenbush, \& Earls, 1997)。近隣地域の集合効力性が 高い地域では，そうでない地域よりも住民の犯罪被害 のリスクが低く（Sampson et al., 1997），個人の精神的 · 身体的健康や幸福度も高いこと（Kawachi, Subramanian, \& Kim, 2008）が実証されている。

\section{共有された関係効力性}

上述のように, 社会認知理論や社会関倸資本論に基 づく研究では, 集団レベルの効力期待が, 個人の精神 的健康や幸福度を予測することが示されてきた。しか し, 二者関係がどのようにして個人の精神的健康や幸 福度を規定するのかを明らかにするためには, 個人レ ベル，集団レベルいずれとも異なる，ダイアドレベル の効力期待に注目する必要がある。

Simmel（1908 堀・居安訳 1972）によると, 個人間 の相互作用を含む二者関係は, 社会の最小構成単位で あり，三者以上で構成される集団とは明確に区別され る(Wolff, 1950)。三者以上からなる集団では, 多数派 に属する集団成員が，個人の行動傾向や心理プロセス

2 そのため本論文では, collective efficacyに対する訳語として, 集合心や集団心を仮定しているかのように読み取れる“集合効 力感”を避けた。
に対して直接的・間接的な影響を与えることが主であ る。これに対して，二者関係では，個人ともう一人の 個人が，相互に直接的な影響を与え合うことになる。 また, 集団は一人の成員が離脱しても維持されうるが, 二者関係はどちらか一方の個人が離脱すると崩壊して しまう。集団と二者関係とのこうした本質的な差異は, 二者関係における相互作用を，三者以上の集団におけ る相互作用とは別個の現象とみなすことの妥当性を示 すものである。本論文でも，ダイアドレベルの効力期 待は, 個人レベルの効力期待のみならず, 集団レベル の効力期待とも区別されるという立場を取る。

近年, こうしたダイアドレベルの効力期待として, 共有された関係効力性の概念が提案されている。共有 された関係効力性とは，良好な関係の形成・維持のた めに必要な行動を, 自己と相手が協力して計画书よび 遂行できるかどうかについて，二者間で共有された効 力期待と定義される (浅野, 2011; 浅野 ·吉田, 2011)。 具体的には，二者関係を形成している両者が，“わた したち二人は，よい関係を築くために協力し合える” と予期している状態を指す。この定義に基づくと, 共 有された関係効力性の高さは, 自己効力感ではとらえ きれない二者の相互調整や相互協調をうながすことが 予測される。たとえば，共有された関係効力性の高い ダイアドは, (a) 個人 A がサポートを提供した場合, 個人 B は負債感を抱かずに感謝を示しながらそのサ ポートを受容し，（b）葛藤時に個人 A が話し合いなど の建設的な対処方略を選択した場合, 個人 B もその 話し合いに応じる，といったことが考えられる。共有 された関係効力性によるダイアドレベルの影響プロセ スは，従来検討されてきた個人レベルの説明変数に起 因する影響プロセスとは異なるものであり，共有され た関係効力性は, 二者双方の総和としての精神的健康 や二者双方の総和としての幸福度を規定するだろう。

共有された関係効力性は，二者関係に扔ける共有さ れた現実感 (shared reality: Echterhoff, 2014; Echterhoff, Higgins, \& Levine, 2009）を基盤に成立すると考えられ る。共有された現実感とは, (a) 直接観察可能な行動 (overt behavior) ではなく, 周囲の世界に対する認知, 感情, 評価, 態度といった内的状態（inner state）に他 者との共通性や類似性がみられる，（b）内的状態を共 通させるべき特定の対象が存在している，(c) 世界を 正しく理解しょうとしたり,他者とのつながりを構築・ 維持しょうとしたりする動機づけに基づいている, (d) 他者との間に内的状態の共通性がみられることを意識 的に経験している, という四つの要件によって定義さ れる。これらの要件がいずれか一つでも欠けると, 共 有された現実感は失われる。

共有された現実感に関する上述した四つの要件のう ち, （a）内的状態の共通性と（d）共通性の意識的経験 は, 共有された関係効力性の成立に不可欠である 
(Figure 2)。内的状態の共通性は, 個人 A と個人 B と の間で効力期待が実際に共通していることを意味す る。これは内的状態にかかわらず，単に個人 A と個 人 B の行動パターンが類似している場合とは区別さ れる。また，共通性の意識的経験は，個人 A と個人 $\mathrm{B}$ の効力期待の共通性を第三者が外部から推測できる だけでなく，それぞれの個人が二者間の効力期待の共 通性を主観的に認識していることを意味する。このよ うに，共有された関係効力性は，二者双方における内 的状態の共有を問題としている。これは，共有された 現実感が，二者関係のどちらか一方の個人における内 的状態の共有を問題としているのとは異なる。

以上のことから，共有された関係効力性は，二者が 共通して“わたしたちはよい関係を築くために互いに 協力し合える”という効力期待をもつと同時に，二者 双方がそのことを意識的に経験することではじめて成
立する。共有された関係効力性は，実体をもつ個人と 個人の相互依存性によって創発された構成概念であ り，社会心理学者が懸念し続けてきた集団錯誤 (Allport, 1924; 亀田・村田, 2010）をもたらすわけでは ない。

共有された関係効力性は, 集合効力性や近隣地域の 集合効力性といった集団レベルの効力期待とは異なる 概念である。集合効力性は，比較的小さな集団からマ クロな社会集団にいたるまで，さまざまなサイズの集 団を含めて定義されている（Bandura, 1997, 2001）。一 方で，共有された関係効力性は，二者関係の文脈に焦 点を当てて定義されている。また，近隣地域の集合効 力性は，住民間の相互作用が少なく，親密性や情緒的 絆を基盤としない“弱い紐帯”（Granovetter, 1973）に おいても, 近隣地域がうまく機能し, 個人が精神的健 康や幸福度を損なわないのはなぜか, といった問題意
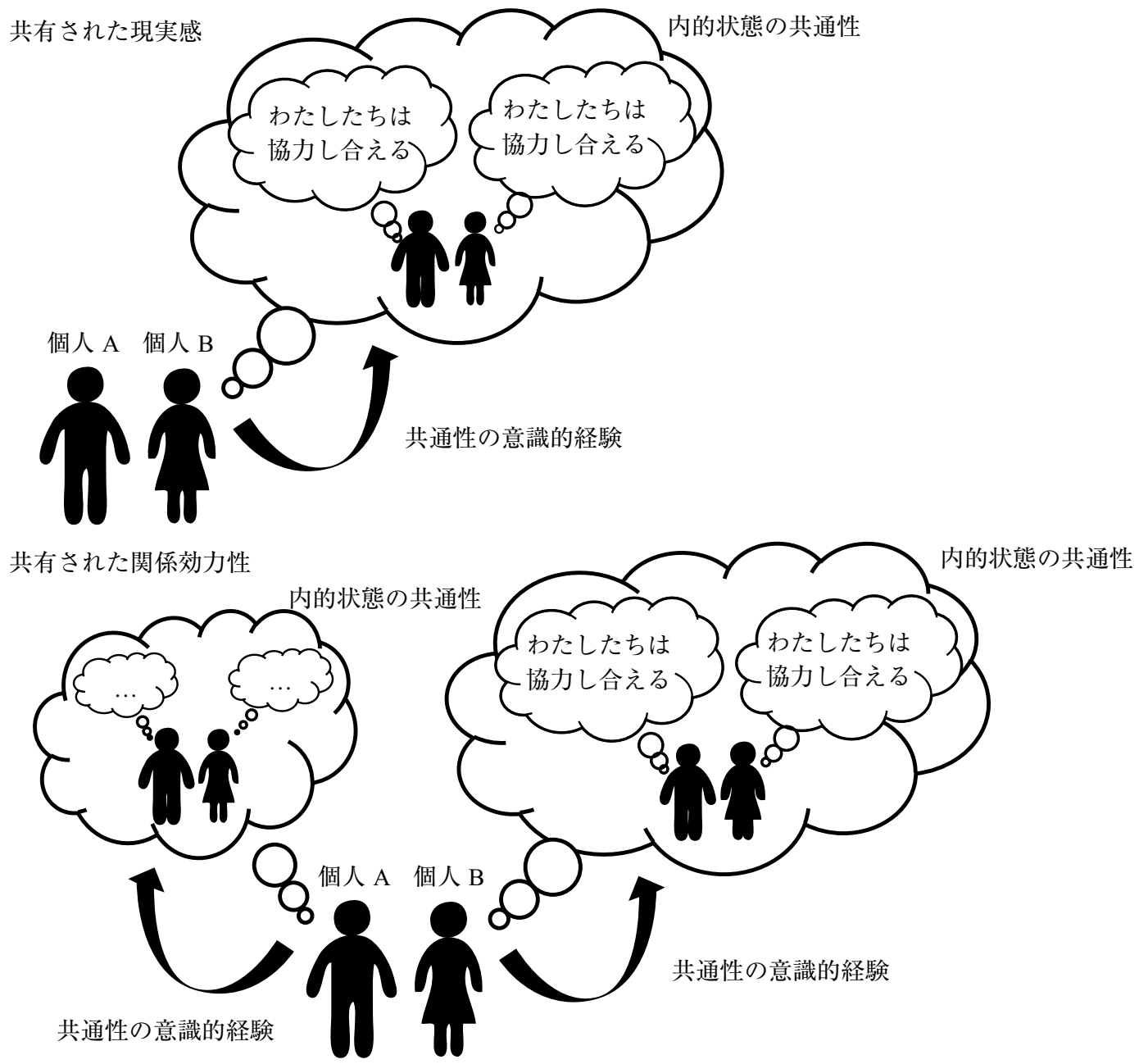

Figure 2. 共有された現実感と共有された関係効力性との関連 
識を背景に概念化されている (Sampson, Morenoff, \& Earls, 1999)。これに対して, 共有された関係効力性は, 親密な関係という“強い紐帯”における個人の精神的 健康や幸福度との関連を元に概念化されている。さら に, 石黒・村上 (2007) は, 行動や態度の共有に関して, 直接的なコミュニケーションが難しい大規模な集団や 近隣地域などの“社会システムにおける共有”と, 直 接的なコミュニケーションが可能な “対人ネットワー クにおける共有”の二つを区別している。この分類に 当てはめると, 一定のサイズをもった大集団における 集合効力性, ならびに近隣地域の集合効力性は, 社会 システムのなかで共有された現実感を基盤としてい る。これに対して，共有された関係効力性は，二者間 での対人コミュニケーションを通じて共有された現実 感を基盤としている。これらのことから，共有された 関係効力性と, 集合効力性や近隣地域の集合効力性は, 互いにある程度類似しているものの，完全に一致する 概念ではない。

\section{二者関係における効力期待の分類}

これまでにも, 特定の二者関係における効力期待の 議論はなされている。たとえば，恋愛関係や夫婦関係 (Doherty, 1981; Fincham, Harold, \& Gano-Phillips, 2000; Murray \& Holmes, 1997), スポーツのチームメイト, 選手-コーチ関係 (Jackson \& Beauchamp, 2010; Jackson, Beauchamp, \& Knapp, 2007) における効力期待が検討 されてきた。しかし, 従来の研究で扱われてきたのは, “わたしは適切に行動することができる”という自己 を主体とした個人レベルの効力期待，すなわち自己効 力感であった。“個人-関係のダイナミックス”の視座 においては, 自己効力感によって導かれる個人レベル の影響プロセスだけでなく，共有された関係効力性に 基づくダイアドレベルの影響プロセスにも目を向ける 必要がある。

二者関係における効力期待を実証的に検討する際に は, (a) 効力期待の主体に関する個人レベルーダイア ドレベルと, (b) 分析モデルに関する個人レベルーダ イアドレベルという直交する二軸によって，以下の四 つの効力期待を区別することが重要となる（Figure 3)。先行研究では, 理論的な観点からみた効力期待の 主体と, 方法論的な観点からみた分析モデルに不一致 がみられたことにより，得られた知見が個人レベルの 影響プロセスを反映しているのか，あるいはダイアド レベルの影響プロセスを反映しているのかがあいまい であった。以下に示す四つの分類は，この点を明確に 整理するものである。

第一に，“わたしは適切に行動することができる” といったように，自己を主体とする個人レベルの構成 概念として理論的に定義され, 分析においても個人レ ベルの影響プロセスが想定されている効力期待は, 知
覚された自己効力感 (perceived self-efficacy) を意味し ている。知覚された自己効力感は, Bandura（1997）の 主張に基づいており，特定の二者関係に特化した効力 期待として，これまでの研究でもたびたび検討されて いる (Doherty, 1981; Fincham et al., 2000)。

第二に，個人レベルの構成概念として理論的には定 義されているが，実際の分析ではダイアドレベルの影 響プロセスが想定されている効力期待は，類似した自 己効力感 (similar self-efficacy) を表している。ここで の類似とは，共有された現実感を基盤とせず，社会的 ネットワーク研究において想定される“影響”のプロ セスのように, 関係の親密化に伴って二者の内的状態 が似通うことを指す。ただし，この分類は理論的に解 釈することが難しく，実証研究で取り上げられること はほとんどない。

第三に,”わたしたちは互いに適切に行動すること ができる”といったように，二者を主体とするダイア ドレベルの構成概念として理論的に定義されながら も，実際の分析では個人レベルの影響プロセスが想定 されている効力期待は, 知覚された関係効力性 (perceived relational efficacy) を表している。知覚され た関係効力性は, 共有された関係効力性についての個 人一人ひとりの認知として解釈でき, Murray \& Holmes（1997）によって検討された効力期待が該当す る。

第四に，ダイアドレベルの構成概念として理論的に 定義され, 分析においてもダイアドレベルの影響プロ セスが想定されている効力期待は，共有された関係効 力性を意味している。本節で議論してきた通り, 共有 された関係効力性は, 内的状態に二者間で共通性がみ られ，そのことを二者双方が意識的に経験している効 力期待を指す。“個人-関係のダイナミックス”に基 づき，共有された関係効力性を実証的に検討すること で，二者双方の精神的健康や二者双方の幸福度を予測

\section{分析モデル}

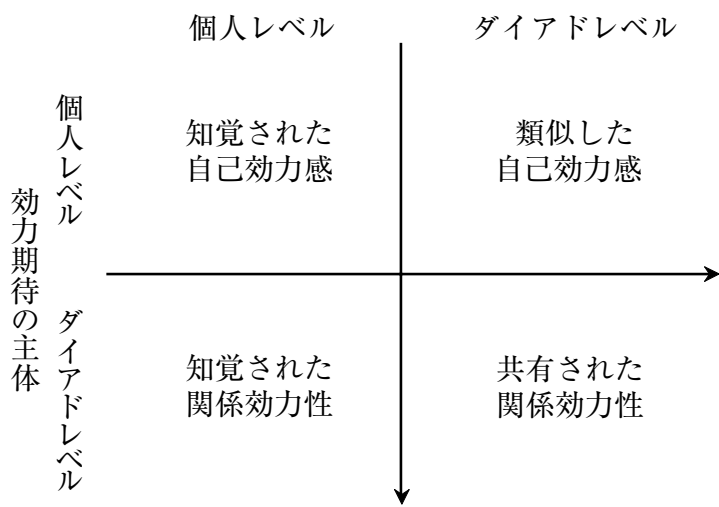

Figure 3. 二者関係における効力期待の分類 
することができる。

\section{共有された関係効力性の分析}

共有された関係効力性が二者双方の精神的健康や二 者双方の幸福度を予測するという，ダイアドレベルの 影響プロセスを実証的に検討するためには，通常の回 帰分析や構造方程式モデリングなどとは異なる分析手 法を用いる必要がある。本節では，ダイアドデータに 特化した解析法として, 行為者一パートナー相互依存 性モデル (Actor-Partner Interdependence Model (APIM) : Kenny, Kashy, \& Cook, 2006), ペアワイズ相関分析 (pairwise correlation analysis: Gonzalez \& Griffin, 1999; Griffin \& Gonzalez, 1995), 共通運命モデル (common fate model: Ledermann \& Kenny, 2012) の三つを概観す る。その上で, マルチレベル構造方程式モデリング (Multilevel Structural Equation Modeling: 以下 MSEMと する, Muthén, 1994, 1997）という新しい手法を取り上 げ, ダイアドデータへの適用可能性について議論する。

\section{ダイアドデータの分析方法}

二者関係や集団といったクラスタに個人がネストさ れている階層デー夕には, 同じクラス夕内の個人が互 いに独立ではないこと（non-interdependence）により， 個人間に類似性がみられるという特徴がある（Figure 4)。そのため, ダイアドデータはサンプルの独立性仮 定という統計学に打ける基本的前提から逸脱してお り，これを考慮しないまま統計分析を行うと第 1 種の 誤りを犯すリスクが高くなる (Kenny et al., 2006; 清水, 2014）。その一方で，こうしたクラス夕内の類似性を うまく利用すれば，ダイアドレベルの影響プロセスを 検証することが可能となる。ダイアドデータを分析す
るための方法としては，以下のモデルが提案されてい る。

APIM は, 個人の説明変数が個人自身の結果変数に 与える影響である行為者効果 (actor effect) と, 個人の 説明変数が相手の結果変数に与える影響であるパート ナー効果 (partner effect) を検討する方法であり (Figure 5a), 現在最も多く用いられているダイアド データの解析手法といえる。また, ペアワイズ相関分 析は，個人-集団レベル相関分析（Kenny \& La Voie, 1985）の枠組みをダイアドデータに適用し，二者の測 定值である観測変数から潜在変数を構成することで, ダイアドレベルを意味する二者間で共有された効果 （shared effect）と，個人レベルを意味する個人独自の 効果（unique effect）を分解し，それぞれのレベルで説 明変数と結果変数との間の相関関係を検討する方法で ある（Figure 5b）。そして，共通運命モデルは，ペア ワイズ相関分析を拡張し，共有された効果と個人独自 の効果を分解した後，それぞれのレベルで変数間の因 果関係，ないしは相関関係を検討する方法である (Figure 5c,5d)。

しかし，上述した三つの分析手法には，“個人-関倸 のダイナミックス”の視座に基づき，共有された関係 効力性が二者双方の精神的健康や二者双方の幸福度に 与える影響を検討するのに不十分な点がある。APIM は, 行為者効果とパートナー効果という個人レベルの 相互影響プロセスを検討するためのモデルであり (Ledermann \& Kenny, 2012)，ダイアドレベルの影響プ ロセスを扱うことができない。ペアワイズ相関分析や 共通運命モデルは, ダイアドレベルと個人レベルの影 響プロセスを検討することはできるが，ダイアドデー 夕に特化した手法であるがゆえに，三者以上の集団に

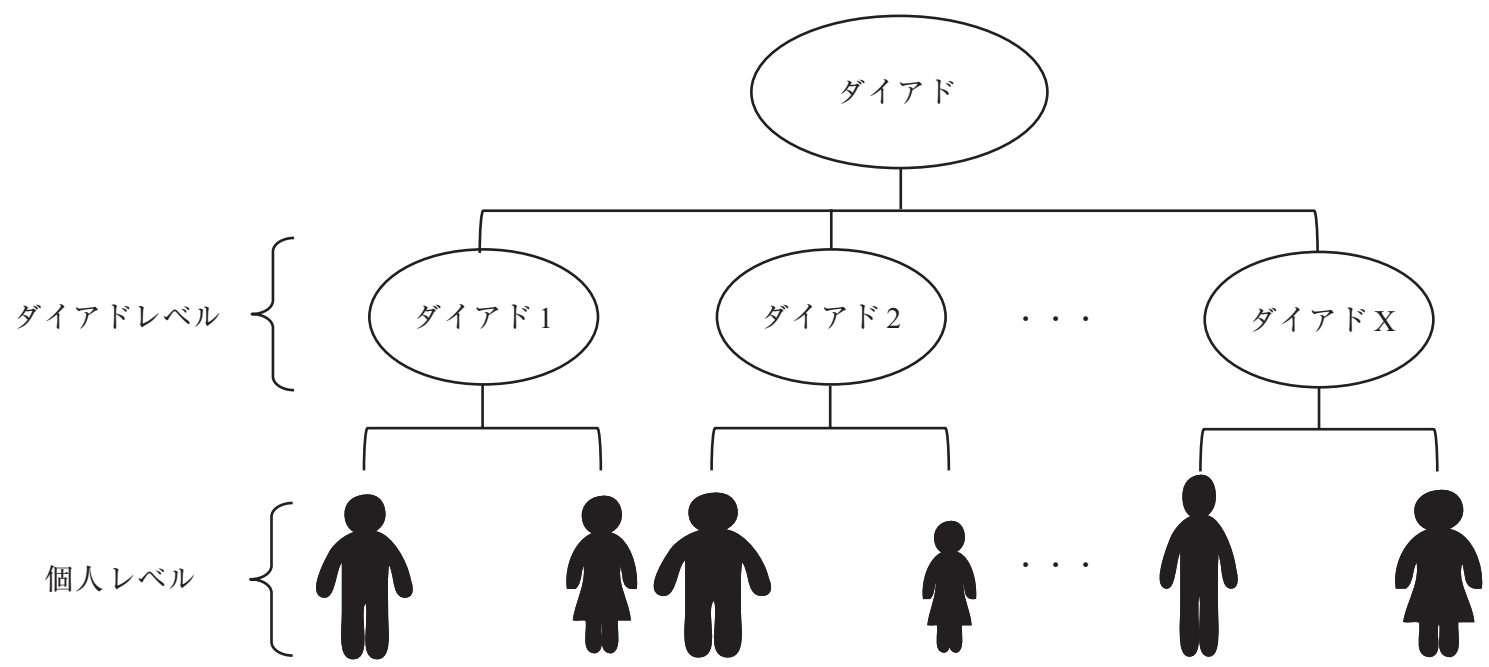

Figure 4. ダイアドデータを例にした階層データの構造 
関する知見との比較やそうした研究への一般化が難し い。また，これら三つの分析方法はいずれも，同性友 人やルームメイトといった識別不可能な (indistinguishable) デー夕を扱う際に，分析前にデー タセットをペアワイズ配列にしたり，推定後に自由度 や適合度を調整したりするといったやや煩雑な処理も 必要になる (Kenny et al., 2006; 清水, 2014; 豊田, 2009)。そこで本論文では，これらの限界を解決する ための手法として，MSEMに焦点を当てる。

\section{マルチレベル構造方程式モデリング}

MSEM とは, データ全体の分散共分散行列を Between と呼ばれるクラスタ間（ダイアドや集団）の 分散共分散行列と, Within と呼ばれるクラス夕内（個 人）の分散共分散行列という二つの成分に分解し，そ れぞれを独立にモデリングする手法である。因子分析

$\mathrm{a}:$ 行為者-パートナー相互依存性モデル

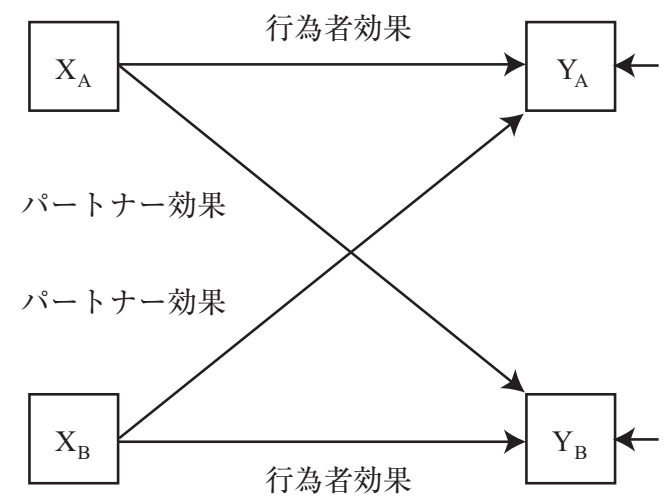

c: 共通運命モデル

個人レベル相関

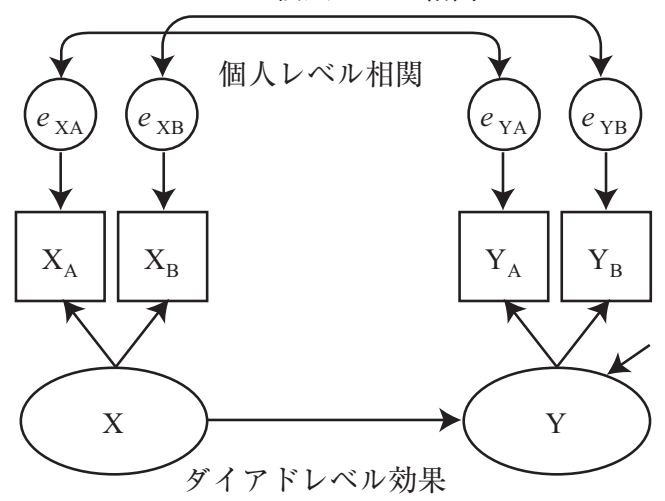

Figure 5. ダイアドデータの分析方法

注) $\mathrm{X}=$ 説明変数, $\mathrm{Y}=$ 結果変数, $\mathrm{A}=$ 個人 $\mathrm{A}, \mathrm{B}=$ 個人 $\mathrm{B}$ 。
において，複数の項目同士の共通成分（因子）と各項 目の独自成分 (誤差) がそれぞれ抽出されるように, MSEMによる分析でも, クラスタ間の共通成分 (Between) とクラスタ内の独自成分 (Within) が切り分 けられ，別個のモデルとして推定される（Figure 6)。 なお， Between と Within が独立ということは，再者は 互いに無相関と仮定されており, Betweenから Within，もしくは Within から Between という異なるモ デルに対してパスを引くことはできない（Muthén, 1994, 1997; 豊田, 2000)。

Between と Within の分解は, 全分散に抒けるクラス 夕間の分散の割合である級内相関係数 (intraclass correlation coefficient）に基づいてなされる。級内相関 係数の高さは, クラス夕間の差異が大きく, クラス夕 内の類似性が高いことを意味する。ダイアドデータの 場合, 級内相関係数は, 個人レベルで測定された変数 b: ペアワイズ相関分析

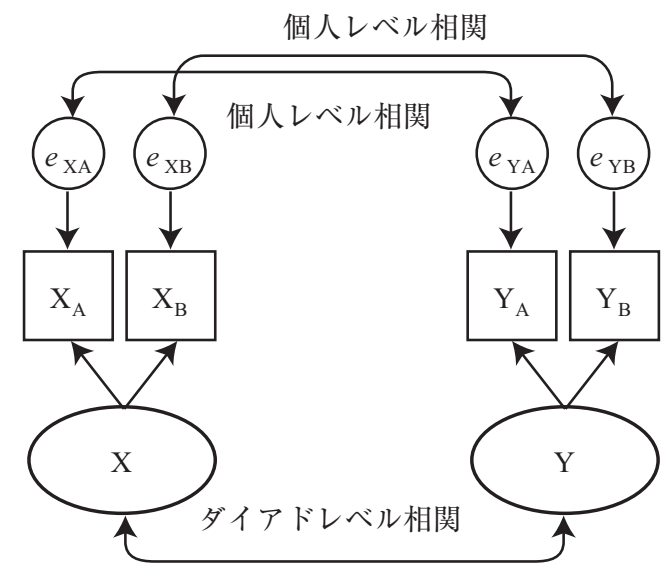

d: マルチレベル共通運命モデル

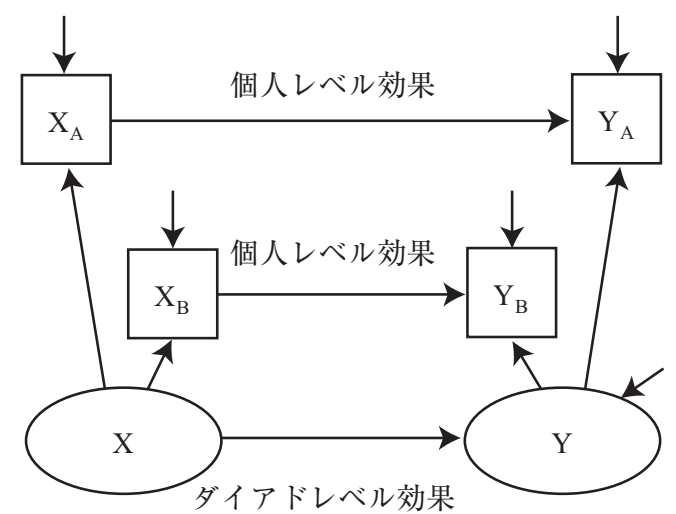


の得点が二者間で共変動している程度として解釈され る。たとえば，二者双方が，“わたしたちはよい関係 を築くために互いに協力し合える”という効力期待を 共有していれば，知覚された関係効力性の測定值は二 者間で共変動する。共有された関係効力性の検討に際 しては，級内相関係数を算出することで，知覚された 関係効力性の共有が二者間でどのくらい生じているの かを定量的に把握できるのである。

\section{マルチレベル構造方程式モデリングの特徵}

これまで，階層デー夕に対しては，マルチレベルモ デル (Multilevel Model: 以下 MLMとする, Raudenbush \& Bryk, 2002)3 を用いるのが一般的であった。MLM では，個人レベルとして解釈する Level 1 と，ダイア ドレベルや集団レベルとして解釈する Level 2 を区別 して扱うことができ，多くの点で MSEM と類似した 特徵をもつ。しかし, 以下の二つの理由から，共有さ れた関係効力性が二者双方の精神的健康や二者双方の 幸福度を規定するというダイアドレベルの影響プロセ スの検討には，MLMよりも，MSEM を用いるほうが ふさわしいと考えられる。

第一に，MSEM を用いることで，Between の説明変 数を潜在変数としてみなすことができる（Lüdtke, Marsh, Robitzsch, Trautwein, Asparouhov, \& Muthén, 2008)。MSEM では, Betweenの結果変数と説明変数 の両方に対して, クラスタ内の個々人の得点から共通 成分を抽出し, 潜在的なクラスタ平均を仮定する結果 指標集計 (reflective aggregation) が用いられる。この 方法は, 集団内の雲囲気や風土, 共有された期待など, 直接観察することの難しい心理学的な構成概念をダイ アドレベルや集団レベルで扱う場合に適している。一 方, MLM では, Level 2 の説明変数に対して, 同じク ラス夕内の個人の得点から直接的にクラス夕平均を算 出する原因指標集計 (formative aggregation) が用いら れる。この方法は, 性別, 年齢, 教育歴, 収入といっ た直接観察しやすい社会学的な要因をダイアドレベル や集団レベルで扱う場合には適しているが，心理学的 な構成概念の分析には必ずしも適さない。こうした集 計法の違いは, 潜在変数から観測変数に対してパスを 引く因子分析と, 観測変数から主成分に対してパスを 引く主成分分析の違いに対応している（Figure 7)。し たがって，原因指標集計に基づくMLM よりも，結果 指標集計に基づくMSEM のほうが，共有された関倸 効力性の概念との整合性は高いといえる。

第二に, Between の説明変数と結果変数との関連に ついて, MSEM は, MLM よりも正確な推定值を算出 することができる (Lüdtke et al., 2008; Marsh, Lüdtke, Robitzsch, Trautwein, Asparouhov, Muthén, \& Nagengast,

3 階層線形モデル (hierarchical linear model) と同義である。
2009)。MSEM では，あらかじめデー夕全体の分散共 分散行列を Between とWithin に分解した上で，それ ぞれのモデルを検討する。しかし，MLMでは，Level 1 で通常の回帰式を組み立てた後に，その回㫶式にお ける切片や傾きが Level 2 ごとに異なるかどうかを検 討する。このような原理からなる MLM をダイアド デー夕に適用した場合, Level 2 の回帰直線は 2 点 (二 者）で完全にあてはまるため，誤差を仮定できないと いう数理的な困難が生じる。そのため, Level 2 のパ スはすべてのダイアドを通して等值である，という非 現実的な仮定を置かざるを得ない (Kenny et al.,

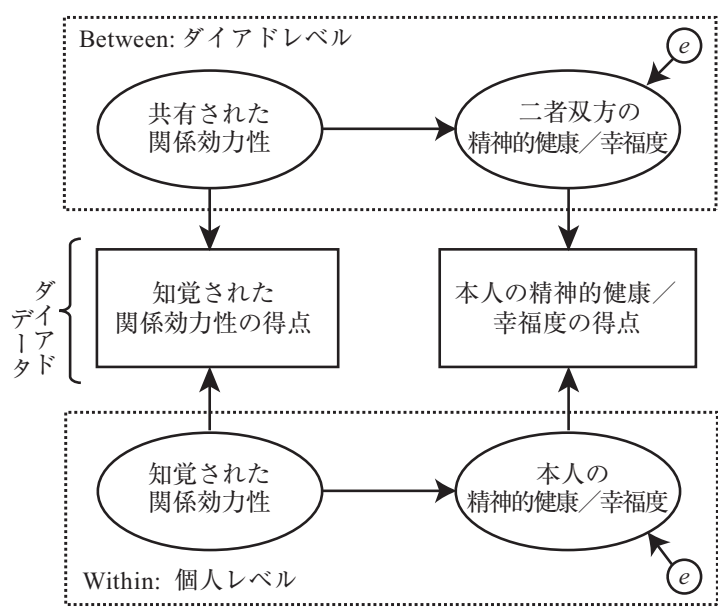

Figure 6. マルチレベル構造方程式モデリングによる共 有された関係効力性と知覚された関係効力性の検討

結果指標集計

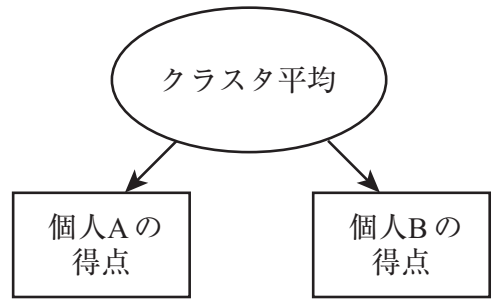

原因指標集計

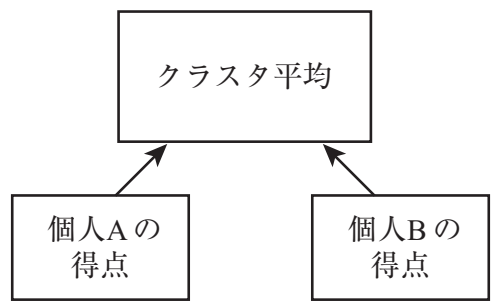

Figure 7. 結果指標集計と原因指標集計 
2006)。また， Lüdtke et al. (2008）は，（a）1 クラスタ あたりの標本サイズ (number of observations per cluster: 5 - 30), (b) クラスタの数 (number of clusters: 5 $500)$ （c）分析に投入される変数の級内相関係数 (.05 —.30）を操作したシミュレーションを行っている。 その結果, 1 クラスタあたりの標本サイズが小さい, クラス夕の数が少ない, そして級内相関係数が低い場 合に, MLM の Level 2 よりも, MSEM の Between は 文脈効果 (contextual effect: クラスタ平均によって構成 された変数の回帰係数) のゆがみを抑えることを報告 した。この知見は実データによっても確認されている (Marsh et al., 2009)。以上のことから, ダイアドデー 夕を用いて共有された関係効力性を検討する際, MSEM を適用するほうが，MLM を適用するよりも， 正確な推定結果を得ることができると考えられる。

ダイアドデータは，1 クラスタあたりの標本サイズ が必然的にわずか 2 となる。こうしたデー夕を扱う二 者関係研究者にとって, 上述した二つの理由は, MSEM を採用する根拠となりうる。また, 社会・パー ソナリティ心理学でよく用いられる媒介分析を行う際 にも, MLM よりも MSEM が推奨されている（Preacher, Zyphur, \& Zhang, 2010)。しかし一方で, MSEM をダ イアドデータに適用すると, モデルの性質上, クラス 夕信頼性の希薄化が起きやすいという限界もある。ク ラスタ信頼性は, クラス夕平均が誤差を含まない“真 の”得点をどのくらい反映しているのかという指標で あり，1クラスタあたりの標本サイズと級内相関係数 によって定義される (Lüdtke et al., 2008; Marsh et al., 2009)。ダイアドデータの場合，分析に投入される変 数の級内相関係数が高かったとしても，1 クラス夕あ たりの標本サイズが小さいために，クラス夕信頼性が 極めて低くなり，MSEMによって推定された文脈効 果は真の值から乘離しやすい。さらに，これまでの研 究では, 1 クラス夕あたりの標本サイズが 2 という状 況における文脈効果のふるまいは直接検討されておら ず，ダイアドデータに対して MSEM を用いることの 妥当性についてはいまだ十分に明らかとなっていな い。したがって現時点では，ダイアドデータに対する MSEMの結果は，慎重に解釈する必要があるといえ よう。

以上の議論から，いくつかの限界はあるものの, MSEM によるダイアドデータの分析は，共有された 関係効力性に関するダイアドレベルの影響プロセスを 実証研究の组上に載せるための有力な方法の一つと考 えられる。

\section{MSEM による分析結果の解釈}

ダイアドデータに対して MSEM を適用する際には, 当該分野の理論や知見と, 分析によって得られる結果 との整合性を詳細に吟味することが不可欠である（清
水，2014）。本論文における主要な説明変数である共 有された関係効力性は, 理論的にダイアドレベルの構 成概念として想定されており，結果指標集計に基づく 個々人の知覚された関係効力性の共通成分は，共有さ れた関係効力性の概念的定義と直接的に対応している と考えられる (Lüdtke et al., 2008)。これに対して，結 果変数である精神的健康や幸福度については，これま での理論や知見を踏まえると, 個人レベルの構成概念 としてとらえるのが妥当である。この場合, 結果指標 集計によって抽出される個々人の精神的健康や幸福度 の共通成分は，あくまでも統計学的な意味での分散の 共変動を表しており，理論的な観点からダイアドレベ ルの構成概念を仮定しているわけではない。MSEM における Between の精神的健康や幸福度は, 当該の二 者関係の文脈のなかで説明できる精神的健康や幸福度 を表しており，これらは“二者双方の総和としての精 神的健康の高さ”, あるいは“二者双方の総和として の幸福度の高さ”と解釈すべきだろう。

精神的健康や幸福度を“個人-関係のダイナミック ス”によって説明する上で，二者双方の精神的健康や 二者双方の幸福度に注目することは重要である。社会 的ネットワーク分析を適用した近年の研究では, 情動 伝染のプロセスを通じて，抑うつや主観的幸福感が ネットワーク内で伝播することが示されている (Fowler \& Christakis, 2008; Rosenquist, Fowler, \& Christakis, 2011)。こうした社会的ネットワークにおけ る情動伝染と同様に，二者関係においても，情動伝染 のプロセスを経ることで，精神的健康や幸福度は個人 間で類似すると考えられる。このことは, 理論的に個 人レベルの構成概念として位置づけられる精神的健康 や幸福度が, 個人レベルの影響プロセスだけでなく, ダイアドレベルの影響プロセスによっても規定される 可能性を示唆している。

このような前提に基づいてダイアドデータを収集 し, 精神的健康や幸福度の指標に一定の級内相関係数 が認められれば，二者双方の精神的健康，あるいは二 者双方の幸福度を実証的に扱うことが可能になる。実 際に，夫婦・恋愛カップルや同性友人ペアを対象とし た調査では, ポジティブ感情やネガティブ感情（浅野, 2011), 人生満足度や人格的成長（浅野・吉田, 2013), 主観的幸福感 (石盛・小杉・清水・藤澤 - 渡邊, 2014) に弱い值から中程度の值の級内相関が報告されてい る。二者双方の総和としての精神的健康，あるいは幸 福度が高いかどうかを取り上げることは，精神的健康 や幸福度を二者関係そのものに起因する部分と, そう でない部分に切り分けた上で，それぞれの規定因を明 らかにする試みに他ならない。これらは, “個人-関係 のダイナミックス”を導入することで, はじめて明ら かになる視点といえよう。

以上の議論から，MSEMによるダイアドデータの 
分析は, 既存の手法とは異なった視点からのモデリン グによって概念間の関連を明らかにすることができ る。その一方で, MSEM で抽出される Between の解 釈については, 理論や先行研究の知見を元に, 既存の 心理構成概念との対応を十分に整理しておくことが重 要である。

\section{“個人-関係のダイナミックス”に関する実証研究}

本節では, “個人-関係のダイナミックス”の視座に 立った先行研究の理論的背景と分析手法を整理した上 で, 先行研究に与える示唆について論じる。ただし, このアプローチはいまだ萌芽期にあり，本節で取り上 げることのできる実証研究は決して多くない上に，必 ずしも個人の精神的健康や幸福度を結果変数としたも のではない。ダイアドデータを扱う研究では, APIM が一般的に用いられ，ペアワイズ相関分析や共通運命 モデルは，その重要性にもかかわらず適用例が非常に 限られている (Ledermann \& Kenny, 2012)。これは, 現在の二者関係研究に拀いて, ダイアドレベルの影響 プロセスに関する理論や仮説がほとんど提案されてい ないことの裏づけといえるだろう。さらに，ダイアド データに対してMSEMを用いた研究も, 現在のとこ ろ，日本国内でしか行われていない。しかし，それで もなお，二者関倸が個人の精神的健康や幸福度に与え る影響を今後より一層深く理解するためには, “個人一 関係のダイナミックス”の視座に関連する研究を概観 することが不可欠と考えられる。

\section{相互作用構造}

“個人-関係のダイナミックス”のアプローチは，二 者関係に拈ける社会的交換をめぐる一連の研究にみら れる。清水・大坊 (2007) は, 二者関係でなされる社 会的交換のパターンを, 頻度 (frequency), 多様性 (diversity), 強度 (strength) という三つの要素からな る相互作用構造として定義し, 関係良好性との関連を ペアワイズ相関分析によって検討した。恋愛カップル に対して質問紙調査を行った結果，ダイアドレベルで は, 二者双方の相互作用構造の多様性ならびに強度と, 二者双方の関係良好性との間に正の関連がみられた。 その一方で, 個人レベルでは, 本人の相互作用構造の 強度と, 本人の関係良好性との間にのみ正の関連がみ られた。その後, 清水・大坊（2008）は, MSEMを用 いてこの結果を再現するとともに，関係良好性に対す る相互作用構造の説明率が, 個人レベルよりもダイア ドレベルにおいて高いことを示した。これらの知見は, 個人レベルの影響プロセスよりも，むしろダイアドレ ベルの影響プロセスによって, 親密な関係が成立して いることを示唆するものである。

\section{二者に共通した状況・環境要因}

“個人-関係のダイナミックス”の視座と関連する研 究として, 二者を取り巻く状況要因や環境要因に目を 向けたものもある。たとえば，夫婦カップルを対象と した質問紙調査のデータに対して, 共通運命モデルに よる媒介分析を行った研究 (Ledermann, Bodenmann, Rudaz, \& Bradbury, 2010) では, ダイアドレベルにおい て, 家事の分担や習慣の不一致など関係内で生じたス トレスフル・イベントは, 直接的に関係の質を低下さ せることが明らかとなった。また，こうしたストレス フル・イベントは, 夫婦間のコミュニケーションの抑 制をもたらすことで，間接的に関係の質を低下させる ことも示された。これは, 二者に共通した状況要因と してのストレスフル・イベントが, 二者双方の関係の 質を規定するというダイアドレベルの影響プロセスを 実証した初めての知見といえる。

\section{共有された関係効力性}

浅野 (2011) は, 集合効力性に関する先行研究 （Bandura, 1997, 2001）に着想を得て, 共有された関係 効力性が二者双方の感情体験を高めるかどうかという ダイアドレベルの影響プロセス，ならびに知覚された 関係効力性が本人の感情体験を高めるかどうかという 個人レベルの影響プロセスを検討した。恋愛カップル を対象とした質問紙調査のデータに対して MSEMを 行った結果, ダイアドレベルでは, 関係継続期間を統 制してもなお，共有された関係効力性は二者双方のポ ジティブ感情を高めることが示された。また, 個人レ ベルにおいても，性別を統制してもなお，知覚された 関係効力性は本人のポジティブ感情を高めることが示 された。この結果は, 二者関係が個人の精神的健康や 幸福度を規定するメカニズムとして，個人レベルの影 響プロセスだけでなく，ダイアドレベルの影響プロセ スを重視する本論文のアプローチの有用性を示唆して いる。

\section{既存の理論への示唆}

以上のように，“個人-関係のダイナミックス”の視 座をもった実証研究は，いまだ十分とはいえないもの の, 少しずつ蓄積され始めている。これまでに，(a) 個人レベルょりもダイアドレベルの影響プロセスにお いて, 相互作用構造の多様性と強度が関係良好性を高 める，（b）ダイアドレベルの影響プロセスにおいて, ストレスフル・イベントは, 直接的ないし間接的に関 係良好性を低下させる，(c) ダイアドレベルの影響プ ロセスでは, 共有された関係効力性が二者双方のポジ ティブ感情を高めると同時に, 個人レベルの影響プロ セスにおいて, 知覚された関係効力性は本人のポジ ティブ感情を高める，といった知見が得られている。 
この他にも, 二者双方の関係の質について, 恋愛カッ プルのデータに対してペアワイズ相関分析を用いた検 討 (Collins \& Feeney, 2000) や, 夫婦カップルのデータ に対して共通運命モデルを用いた検討 (Matthews, Conger, \& Wickrama, 1996）もなされている。二者関係 が個人の精神的健康や幸福度に与える影響をめぐる今 後の研究でも，本論文のアプローチを積極的に採用し ていくことが望まれる。

“個人-関係のダイナミックス”の視座は, ソシオメー ター理論（Leary \& Baumeister, 2000）や成人の愛着理 論（Mikulincer \& Shaver, 2003）といった従来の枠組み にも有益な示唆を提供する。ここまでの本論文におけ る議論では，二者関係が個人の精神的健康や幸福度に 与える影響を精緻に理解するために，特性自尊心や愛 着スタイルなどによる個人レベルの影響プロセスに加 えて，共有された関倸効力性をはじめ，二者の相互依 存性によって創発されるダイアドレベルの影響プロセ スに注目することの意義を示してきた。個人の精神的 健康や幸福度に対して，ダイアドレベルの説明変数と 個人レベルの説明変数は，それぞれ独立した効果をも つことが考えられ，近年の統計解析の発展がこうした 新たなモデルの実証的検討を後押ししている。

個人の精神的健康や幸福度を“個人-関係のダイナ ミックス”によって説明する視座に基づくアプローチ は，個人レベルとダイアドレベルの主効果や，二つの レベルの交互作用効果に関する詳細な検討を可能にす る。たとえば，“特性自尊心や愛着スタイルにかかわ らず，共有された関係効力性の高さは，二者双方の精 神的健康や幸福度を増進する”というダイアドレベル の主効果のみならず，“共有された関係効力性の高さ は，特性自尊心が低い個人や関係不安が高い個人の精 神的健康や幸福度を維持する”といった交互作用効果 を検証することもできる。本論文の視座は，個人レべ ルの影響プロセスを中心とする従来のモデルが見落と してきた点を補い，二者関係がどのようにして個人の 精神的健康や幸福度を規定するのかを包括的に理解す るための一助となるだろう。

\section{総合考察}

本論文の目的は，個人の精神的健康や幸福度を“個 人-関係のダイナミックス”によって説明する視座を 導入し，そのための方法論として，ダイアドデータの 分析手法について検討することであった。まず，これ までの研究において, 個人の精神的健康や幸福度の源 泉としての二者関係の性質が，主に特性自尊心や愛着 スタイルといった個人レベルの影響プロセスに還元さ れてきたことを明らかにした。つぎに，社会認知理論 や社会関係資本論を踏まえ，共有された関係効力性と いうダイアドレベルの説明変数を取り上げるととも に，その分析手法としてマルチレベル構造方程式モデ
リングに注目した。最後に，本論文のアプローチと関 連する実証研究として, 相互作用構造, 二者を取り巻 く状況・環境要因, 共有された関係効力性に関する知 見を概観した。個人レベルとダイアドレベルの両方の 影響プロセスに目を向ける本論文のアプローチは，個 人の“こころ”や“あたま”を研究の中心としてきた 従来の社会心理学の枠組みを越えて, 二者関係が個人 の精神的健康や幸福度を規定するメカニズムを，より 精緻かつダイナミカルにとらえることを可能にするだ ろう。

“個人-関係のダイナミックス”の視座に基づくアプ ローチは, 今後の心理学研究のあり方そのものにも一 石を投じる。個人と集団，ないしは社会との関係を扱 う社会心理学は, 集団錯誤や方法論的個人主義の問題 を認識しつつも, 個人レベルの要因のみを扱う理論や 研究デザインを見直すべき時期に来ている (Oishi et al., 2009)。個人の精神的健康や幸福度を予測しょうす る今後の研究では, ダイアドレベル，もしくは集団レ ベルの説明変数を取り入れたパラダイム・シフトが不 可欠と考えられる。

また, 本論文の視座は, 社会心理学やパーソナリティ 心理学への示唆だけにとどまらず，より応用実践的な 視野をもった家族心理学, 教育心理学, 健康心理学, 臨床心理学, ポジティブ心理学といった諸分野との架 け橋になりうるという点でも意義深い。より具体的に は，二者関係を対象とした個人の精神的健康や幸福度 の維持・増進を目的とした, 新しいトレーニングやプ ログラムの開発につながる可能性を有している。

たとえば，共有された現実感の実験パラダイム （Echterhoff et al., 2009）に基づくと，まず個人 A が話 し手となり，聞き手である個人 B の知覚された関係 効力性に一致するような発言をすることで, 個人 A の知覚された関倸効力性もそれに合わせて変化するこ とが予測される。その後, 個人 A と B が役割を交代 して同様の手続きを行う。これにより，個人 A と B の知覚された関係効力性の共有をうながすことができ れば，共有された関係効力性が高まり，二者双方の精 神的健康や二者双方の幸福度も促進される可能性があ る。このように, 個人レベルの影響プロセスとともに, ダイアドレベルの影響プロセスにも注目することは, 心理学に打ける人間観を拡張するだけではなく, 研究 成果を社会に還元するという意味でも大きな意義をも つだろう。

将来の研究に向けた課題と展望としては, 大きく以 下の 3 点が挙げられる。第一に, 個人の精神的健康や 幸福度を“個人-関係のダイナミックス”によって説 明するアプローチは, その端緒についたばかりであり， 実証的知見の蓄積にそしい。社会心理学や家族心理学 の領域では, ダイアドレベルの影響プロセスを検証す るためのさまざまな分析手法が提案されてきた。その 
一方で，それらを生かした理論や仮説は，ほとんど提 案されていないのが実情である（Ledermann \& Kenny， 2012)。Van Lange（2013）は, （a）真実性（truth），(b) 抽象性 (abstraction), (c) 発展性 (progress), (d) 応用 可能性 (applicability) という四つの観点から社会心理 学理論の質を問うべきと主張しており, 過去にもこれ らを満たさない理論は淘汰されてきたと指摘してい る。今後は, これら四つの点を考慮しながら実証研究 を積み重ねていくことで, 本論文で提案されたアプ ローチの質を高めることが求められる。

第二に, “個人-関係のダイナミックス”に基づいた 研究の方法論についても, 十分に議論されているとは いえない。本論文で概観した“個人-関係のダイナミッ クス”に関する実証研究は，いずれも調査法によって 測定された認知や知覚を分析対象としたものであっ た。しかし, 行動科学としての社会心理学では, 実験 法や観察法によって直接観察可能な行動を測定するこ とも重要である (Baumeister, Vohs, \& Funder, 2007)。た とえば，共有された現実感や集団間関係に関する実験 (Echterhoff et al., 2009; 岡本 - 藤原 - 野波 - 加藤, 2008）を参考に，会話中の二者の発話内容や非言語行 動の変遷をとらえ，これらが共有された関係効力性と 二者双方の精神的健康，ならびに二者双方の幸福度と の関連を媒介するかどうかについて検討することも必 要だろう。

第三に, ダイアドレベルの影響プロセスを重視した 本論文のアプローチに，メゾレベルとしての集団や， マクロレベルとしての社会構造といった視点を付与す ることも重要である。メゾレベルの視点においては, 二者関係を取り巻く第三者との社会的ネットワーク が, 個人の精神的健康や幸福度に影響を与えることが 予測される（相馬・山内・浦, 2003）。また, マクロレ ベルの視点では, 国や近隣地域ごとの人口移動を指す 居住地の流動性（residential mobility）をはじめとした 社会生態学的環境の違いと, 人々の行動傾向や心理プ ロセスとの関連が明らかにされている(Oishi, 2010, 2014; Yamagishi, Hashimoto, Li, \& Schug, 2012)。今後は, ダイアドレベルのみならず, メゾレベルやマクロレベ ルを包含した“個人-社会のダイナミックス”へとモ デルを拡張することで, 個人の精神的健康や幸福度を より統合的に理解することが期待される。

社会のなかで生きるわれわれにとって, 二者関係は, 精神的健康や幸福度の重要な規定因である。“個人一関 係のダイナミックス”の視座に基づいて, 個人の精神 的健康や幸福度の維持・増進に資する知見を社会に提 供していくことは, 今後の心理学における大きな課題 といえるだろう。

\section{文献}

Acitelli, L. K., Duck, S., \& West, L. (2000). Embracing the social in personal relationships and research. In W. Ickes \& S. Duck (Eds.), The social psychology of personal relationships. Chichester, UK: John Wiley \& Sons. pp. $215-227$.

Allport, F. H. (1924). The group fallacy in relation to social science. American Journal of Sociology, 29, 688-706.

Anderson, C., Keltner, D., \& John, O. P. (2003). Emotional convergence between people over time. Journal of Personality and Social Psychology, 84, 1054-1068.

浅野 良輔 (2011). 恋愛関係における関係効力性が感 情体験に及ぼす影響——者の間主観的な効力期 待の導入一一社会心理学研究, 27, 41-46.

(Asano, R. (2011). Effects of relational efficacy on emotional experiences in romantic relationships: An intersubjective efficacy expectation. Japanese Journal of Social Psychology, 27, 41-46.)

浅野 良輔・吉田 俊和 (2011). 関係効力性が二つの 愛着機能に及ぼす影響——恋愛関係と友人関係の 検討— 心理学研究, 82, 175-182.

(Asano, R., \& Yoshida, T. (2011). Effects of relational efficacy on two attachment functions: Evidence from romantic relationships and same-sex friendships. Japanese Journal of Psychology, 82, 175-182.)

浅野 良輔・吉田 俊和 (2013). なぜ対人関係は幸福 度の源泉たりえるのかー 3 時点の縦断ペアデー 夕による関係効力性の媒介効果の検討一日本 グループ・ダイナミックス学会第 60 回大会発表 論文集, 164-165.

(Asano, R., \& Yoshida, T.)

Bandura, A. (1997). Self-efficacy: The exercise of control. NY: Freeman.

Bandura, A. (2001). Social cognitive theory: An agentic perspective. Annual Review of Psychology, 52, 1-26.

Barsade, S. G. (2002). The ripple effect: Emotional contagion and its influence on group behavior. Administrative Science Quarterly, 47, 644-675.

Bartholomew, K., \& Horowitz, L. M. (1991). Attachment styles among young adults: A test of a four-category model. Journal of Personality and Social Psychology, 61, 226-244.

Baumeister, R. F., Campbell, J. D., Krueger, J. I., \& Vohs, K. D. (2003). Does high self-esteem cause better performance, interpersonal success, happiness, or healthier lifestyles? Psychological Science in the Public Interest, 4, $1-44$.

Baumeister, R. F., Vohs, K. D., \& Funder, D. C. (2007). Psychology as the science of self-reports and finger movements: Whatever happened to actual behavior? Perspectives on Psychological Science, 2, 396-403.

Ben-Ari, A., \& Lavee, Y. (2005). Dyadic characteristics of individual attributes: Attachment, neuroticism, and their relation to marital quality and closeness. American Journal of Orthopsychiatry, 75, 621-631.

Berscheid, E. (1999). The greening of relationship science. 
American Psychologist, 54, 260-266.

Bowlby, J. (1988). A secure base: Parent-child attachment and healthy human development. New York: Basic Books.

Byrne, D., \& Nelson, D. (1965). Attraction as a linear function of proportion of positive reinforcements. Journal of Personality and Social Psychology, 1, 659-663.

Campbell, L., \& Rubin, H. (2012). Modeling dyadic processes. In L. Campbell, J. La Guardia, J. Olson, \& M. Zanna (Eds.), The science of the couple: The Ontario symposium. Vol. 12. New York: Psychology Press. pp. $1-15$.

Cohen, S., \& Wills, T. A. (1985). Stress, social support, and the buffering hypothesis. Psychological Bulletin, 98, 310-357.

Collins, N. L., \& Feeney, B. C. (2000). A safe haven: An attachment theory perspective on support seeking and caregiving in intimate relationships. Journal of Personality and Social Psychology, 78, 1053-1073.

Doherty, W. J. (1981). Cognitive processes in intimate conflict: II. Efficacy and learned helplessness. American Journal of Family Therapy, 9, 35-44.

Echterhoff, G. (2014), Achieving commonality in interpersonal communication: Shared reality and memory processes. Asian Journal of Social Psychology, 17, 104107.

Echterhoff, G., Higgins, E. T., \& Levine, J. M. (2009). Shared reality: Experiencing commonality with others' inner states about the world. Perspectives on Psychological Science, 4, 496-521.

Eisenberger, N. I., \& Cole, S. W. (2012). Social neuroscience and health: Neurophysiological mechanisms linking social ties with physical health. Nature Neuroscience, 15, 669-674.

Feeney, B. C. (2004). A secure base: Responsive support of goal strivings and exploration in adult intimate relationships. Journal of Personality and Social Psychology, 87, 631-648.

Feeney, B. C., \& Collins, N. L. (2015). A new look at social support: A theoretical perspective on thriving through relationships. Personality and Social Psychology Review, 19, 113-147.

Fincham, F. D., Harold, G. T., \& Gano-Phillips, S. (2000). The longitudinal association between attributions and marital satisfaction: Direction of effects and role of efficacy expectations. Journal of Family Psychology, 14, 267-285.

Fowler, J. H., \& Christakis, N. A. (2008). Dynamic spread of happiness in a large social network: Longitudinal analysis over 20 years in the Framingham Heart Study. British Medical Journal, 337 (a, 2338), 1-9.

Gonzaga, C. G., Campos, B., \& Bradbury, T. (2007). Similarity, convergence, and relationship satisfaction in dating and married couples. Journal of Personality and Social Psychology, 93, 34-48.

Gonzalez, R., \& Griffin, D. (1999). The correlational analysis of dyad-level data in the distinguishable case. Personal Relationships, 6, 449-469.
Granovetter, M. S. (1973). The strength of weak ties. American Journal of Sociology, 78, 1360-1380.

Griffin, D., \& Gonzalez, R. (1995). Correlational analysis of dyad-level data in the exchangeable case. Psychological Bulletin, 118, 430-439.

Gully, S. M., Incalcaterra, K. A., Joshi, A., \& Beaubien, J. M. (2002). A meta-analysis of team-efficacy, potency, and performance: Interdependence and level of analysis as moderators of observed relationships. Journal of Applied Psychology, 87, 819-832.

橋本 剛（2005). ストレスと対人関係 ナカニシヤ出 版

(Hashimoto. T.)

Hatfield, E., Cacioppo, J. T., \& Rapson, R. L. (1993). Emotional contagion. Current Directions in Psychological Science, 2, 96-100.

House, J. S., Landis, K. R., \& Umberson, D. (1988). Social relationships and health. Science, 241, 540-545.

Ickes, W., Hutchison, J., \& Mashek, D. (2004). Closeness as intersubjectivity: Social absorption and social individuation. In D. J. Mashek \& A. Aron (Eds.), Handbook of closeness and intimacy. Mahwah, NJ: Erlbaum. pp. 357 -373 .

石黒 格・村上 史朗 (2007). 態度と行動の共有が自 己卑下的自己呈示に及ぼす効果 社会心理学研 究, 23, 130-139.

(Ishiguro, I., \& Murakami, F. (2007). The effects of shared attitudes and behavior on self-effacement. Japanese Journal of Social Psychology, 23, 130-139.)

石盛 真徳 - 小杉 考司 · 清水 裕士 ·藤澤 隆史 · 渡邊 太 (2014)。家族システムの発達と移行に関する 研究—夫婦ペアデータのマルチレベル相関分析 日本グループ・ダイナミックス学会第 61 回大会発表論文集，196-197.

(Ishimori, M., Kosugi, K., Shimizu, H., Fujisawa, T., \& Watanabe, F.)

Jackson, B., \& Beauchamp, M. R. (2010). Efficacy beliefs in coach-athlete dyads: Prospective relationships using actor-partner interdependence models. Applied Psychology: An International Review, 59, 220-242.

Jackson, B., Beauchamp, M. R., \& Knapp, P. (2007). Relational efficacy beliefs in athlete dyads: An investigation using actor-partner interdependence models. Journal of Sport \& Exercise Psychology, 29, 170-189.

Kahneman, D., Diener, E., \& Schwarz, N. (Eds.) (1999). Well-being: The foundations of hedonic psychology. New York: Russell Sage Foundation.

Kahneman, D., \& Krueger, A. B. (2006). Developments in the measurement of subjective well-being. Journal of Economic Perspectives, 20, 3-24.

亀田 達也・村田 光二 (2010). 複雑さに挑む社会心 理学—適応エージェントとしての人間——改 訂版 有斐閣

(Kameda, T., \& Murata, K.)

金政 祐司 (2009). 青年期の母-子ども関係と恋愛関 係の共通性の検討一一青年期の二つの愛着関係に おける悲しき予言の自己成就——社会心理学研 究, 25, 11-20. 
(Kanemasa, Y. (2009). The commonality between mother-child and romantic dyads in early adults: Tragic self-fulfilling prophecies in two attachment relationships in early adults. Japanese Journal of Social Psychology, 25, 11-20.)

金政 祐司 (2010). 中年期の夫婦関係において成人の 愛着スタイルが関係内での感情経験ならびに関係 への評価に及ぼす影響 パーソナリティ研究，19, $134-145$.

(Kanemasa, Y. (2010). Effects of adult attachment styles on emotional experiences in marital relationships and evaluations of the relationships in middleage couples. Japanese Journal of Personality, 19, 134 -145 .)

Kawachi, I., Subramanian, S. V., \& Kim, D. (2008). Social capital and health. New York: Springer.

Kelley, H. H., \& Thibaut, J. W. (1978). Interpersonal relations: A theory of interdependence. New York: John Wiley.

(ケリー, H. H.・ティボー, J.W. 黒川 正流(監訳) (1995). 対人関係論 誠信書房)

Kenny, D. A., Kashy, D. A., \& Cook, W. L. (2006). Dyadic data analysis. New York: Guilford Press.

Kenny, D. A., \& La Voie, L. (1985). Separating individual and group effects. Journal of Personality and Social Psychology, 48, 339-348.

Leary, M. R. (2005). Sociometer theory and the pursuit of relational value: Getting to the root of self-esteem. European Review of Social Psychology, 16, 75-111.

Leary, M. R., \& Baumeister, R. F. (2000). The nature and function of self-esteem: Sociometer theory. In M. P. Zanna (Ed.), Advances in experimental social psychology. Vol. 32. San Diego, CA: Academic Press. pp. 162.

Leary, M. R., Tambor, E. S., Terdal, S. K., \& Downs, D. L. (1995). Self-esteem as an interpersonal monitor: The sociometer hypothesis. Journal of Personality and Social Psychology, 68, 518-530.

Ledermann, T., Bodenmann, G., Rudaz, M., \& Bradbury, T. N. (2010). Stress, communication, and marital quality in couples. Family Relations, 59, 195-206.

Ledermann, T., \& Kenny, D. A. (2012). The common fate model for dyadic data: Variations of a theoretically important but underutilized model. Journal of Family Psychology, 26, 140-148.

Lewin, K. (1947). Frontiers in group dynamics: Concept, method and reality in social science, social equilibria and social change. Human Relations, 1, 5-41.

Lüdtke, O., Marsh, H. W., Robitzsch, A., Trautwein, U., Asparouhov, T., \& Muthén, B. (2008). The multilevel latent covariate model: A new, more reliable approach to group-level effects in contextual studies. Psychological Methods, 13, 203-229.

Marsh, H. W., Lüdtke, O., Robitzsch, A., Trautwein, U., Asparouhov, T., Muthén, B., \& Nagengast, B. (2009). Doubly-latent models of school contextual effects: Integrating multilevel and structural equation approaches to control measurement and sampling error.
Multivariate Behavioral Research, 44, 764-802.

Matthews, L. S., Conger, R. D., \& Wickrama, K. A. S. (1996). Work-family conflict and marital quality: Mediating processes. Social Psychology Quarterly, 59, 62-79.

Mikulincer, M., \& Shaver, P. R. (2003). The attachment behavioral system in adulthood: Activation, psychodynamics, and interpersonal processes. In M. P. Zanna (Ed.), Advances in experimental social psychology. Vol. 35. New York: Academic Press. pp. 53-152.

Murray, S. L., \& Holmes, J. G. (1997). A leap of faith? Positive illusions in romantic relationships. Personality and Social Psychology Bulletin, 23, 586-604.

Murray, S. L., Rose, P., Holmes, J. G., Derrick, J., Podchaski, E. J., Bellavia, G., \& Griffin, D. W. (2005). Putting the partner within reach: A dyadic perspective on felt security in close relationships. Journal of Personality and Social Psychology, 88, 327-347.

Muthén, B. (1997). Latent variable modeling of longitudinal and multilevel data. Sociological Methodology, 27, 453-480.

Muthén, B. O. (1994). Multilevel covariance structure analysis. Sociological Methods \& Research, 22, 376-398.

大石 繁宏 (2009). 幸せを科学する—心理学からわ かったこと——新曜社

(Oishi, S.)

Oishi, S. (2010). The psychology of residential mobility: Implications for the self, social relationships, and wellbeing. Perspectives on Psychological Science, 5, 5-21.

Oishi, S. (2014). Socioecological psychology. Annual Review of Psychology, 65, 581-609.

Oishi, S., Kesebir, S., \& Snyder, B. H. (2009). Sociology: A lost connection in social psychology. Personality and Social Psychology Review, 13, 334-353.

岡本 卓也 - 藤原 武弘・野波 寛 - 加藤 潤三 (2008). 共有集団イメージ法を用いた集団間関係の解析の 試み 実験社会心理学研究, 48, 1-16.

(Okamoto, T., Fujihara, T., Nonami, H., \& Kato, J. (2008). Measurement of intergroup relations using the shared group image method. Japanese Journal of Experimental Social Psychology, 48, 1-16.)

Preacher, K. J,. Zyphur, M. J., \& Zhang, Z. (2010). A general multilevel SEM framework for assessing multilevel mediation. Psychological Methods, 15, 209-233.

Putnam, R. D. (2000). Bowling alone: The collapse and revival of American community. New York: Simon \& Schuster.

（パットナム， R. D. 柴内 康文（訳）（2006）。孤 独なボウリング——米国コミュニティの崩壊と再 生——柏書房)

Raudenbush, S. W., \& Bryk, A. S. (2002). Hierarchical linear models: Applications and data analysis methods. 2nd ed. Thousand Oaks, CA: Sage.

Rholes, W. S., Simpson, J. A., Kohn, J. L., Wilson, C. L., Martin III, A. M., Tran, S., \& Kashy, D. A. (2011). Attachment orientations and depression: A longitudinal study of new parents. Journal of Personality and Social Psychology, 100, 567-586. 
Rosenquist, J. N., Fowler, J. H., \& Christakis, N. A. (2011). Social network determinants of depression. Molecular Psychiatry, 16, 273-281.

Ryan, R. M., \& Deci, E. L. (2001). On happiness and human potentials: A review of research on hedonic and eudaimonic well-being. Annual Review of Psychology, 52, $141-166$.

Sampson, R. J., Morenoff, J. D., \& Earls, F. (1999). Beyond social capital: Spatial dynamics of collective efficacy for children. American Sociological Review, 64, 633660.

Sampson, R. J., Morenoff, J. D., \& Gannon-Rowley, T. (2002). Assessing "neighborhood effects": Social processes and new directions in research. Annual Review of Sociology, 28, 443-478.

Sampson, R. J., Raudenbush, S. W., \& Earls, F. (1997). Neighborhoods and violent crime: A multilevel study of collective efficacy. Science, 277, 918-924.

清水 裕士 (2014). 個人と集団のマルチレベル分析 ナカニシヤ出版

(Shimizu, H.)

清水 裕士 ・大坊 郁夫 (2007). 恋愛関係の相互作用 構造と関係安定性の関連——ップルデータへの ペアワイズ相関分析の適用——社会心理学研 究, 22, 295-304.

(Shimizu, H., \& Daibo, I. (2007). Clarifying the association between structure of interaction and stability of romantic relationships: Application of pairwise correlation analysis into dyad data. Japanese Journal of Social Psychology, 22, 295-304.)

清水 裕士 ・大坊 郁夫 (2008). 恋愛関係における相 互作用構造の研究——階層的デー夕解析による間 主観性の分析— 心理学研究, 78, 575-582.

(Shimizu, H., \& Daibo, I. (2008). The structure of interaction in romantic relationships: Hierarchical data analysis of inter-subjectivity between partners. Japanese Journal of Psychology, 78, 575-582.)

Simmel, G. (1908). Soziologie: Untersuchungen über die formen der vergesellschaftung. Berlin: Duncker \& Humblot.

（ジンメル，G. 堀 喜望・居安 正（訳）（1972）. 集団の社会学 ミネルヴァ書房)

Simpson, J. A., \& Rholes, W. S. (2004). Anxious attatchment and depressive symptoms: An interpersonal perspective. In W. S. Rholes \& J. A. Simpson (Eds.), Adult attachment: Theory, research, and clinical implications. New York: Guilford Press. pp. 408-437.

(シンプソン, J. A.・ロールズ, W. S. 金政 祐司 (訳) (2008). 不安的アタッチメントと抑うつ症 状——対人関係の展望—— W. S. ロールズ・J.A シンプソン (編著) 遠藤 利彦・谷口 弘一・金政 祐司・串崎 真志 (監訳) 成人のアタッチメント
一一理論 - 研究 · 臨床——北大路書房 pp. 367 -394.)

Simpson, J. A., Rholes, W. S., Campbell, L., Tran, S., \& Wilson, C. L. (2003). Adult attachment, the transition to parenthood, and depressive symptoms. Journal of Personality and Social Psychology, 84, 1172-1187.

相馬 敏彦 ·山内 隆久 · 浦 光博 (2003). 恋愛 ・ 結婚 関係における排他性がそのパートナーとの葛藤時 の対処行動選択に与える影響 実験社会心理学研 究, 43, 75-84.

(Souma, T., Yamauchi, T., \& Ura, M. (2003). Selections of coping behavior to interpersonal conflict with a romantic partner as a function of exclusivity in the romantic relationships. Japanese Journal of Social Psychology, 43, 75-84.)

Sowislo, J. F., \& Orth, U. (2013). Does low self-esteem predict depression and anxiety? A meta-analysis of longitudinal studies. Psychological Bulletin, 139, 213 -240 .

Stajkovic, A. D., Lee, D., \& Nyberg, A. J. (2009). Collective efficacy, group potency, and group performance: Meta-analyses of their relationships, and test of a mediation model. Journal of Applied Psychology, 94, $814-828$

豊田 秀樹 (2000)。共分散構造分析 “応用編” ——構 造方程式モデリング——朝倉書店

(Toyoda, H.)

豊田 秀樹（編著）（2009）。共分散構造分析 “実践編” —構造方程式モデリング——朝倉書店 (Toyoda, H.)

浦 光博 (1992). 支えあう人と人——ソーシャル・サ ポートの社会心理学——サエンス社 (Ura, M.)

浦 光博 (2009). 排斥と受容の行動科学——社会と心 が作り出す孤立—— サイエンス社 (Ura, M.)

Van Lange, P. A. M. (2013). What we should expect from theories in social psychology: Truth, Abstraction, Progress, and Applicability as Standards (TAPAS). Personality and Social Psychology Review, 17, 40-55.

Wolff, K. H. (1950). The sociology of Georg Simmel. Glencoe, IL: Free Press.

Yamagishi, T., Hashimoto, H., Li, Y., \& Schug, J. (2012). Stadtluft macht frei (City air brings freedom). Journal of Cross-Cultural Psychology, 43, 38-45.

Zaccaro, S., Blair, V., Peterson, C., \& Zananis, M. (1995). Collective efficacy. In J. E. Maddux (Ed.), Selfefficacy, adaptation, and adjustment: Theory, research, and application. New York: Plenum. pp. 305-330.

- 2014. 7.22 受稿, 2015.5.16 受理 — 